\title{
Estimation of Potential Evapotranspiration at Botanga Irrigation Scheme in the Northern Region of Ghana
}

\author{
Adams Sadick ${ }^{1}$, Isaac Owusu Ansah ${ }^{1}$, Aaron Owusu Badu ${ }^{1}$, Kwabena \\ Abrefa Nketia $^{2}$, Eric Asamoah ${ }^{2}$, Jerry Asaana ${ }^{3}$, Richard Amfo-Otu ${ }^{4}$ \\ ${ }^{1}$ Soil Chemistry and Mineralogy Division, CSIR-Soil Research Institute, Kumasi, Ghana \\ ${ }^{2}$ Soil Genesis, Survey and Evaluation Division, CSIR-Soil Research Institute, Kumasi, Ghana \\ ${ }^{3}$ Bolgatanga Polytechnic, Bolgatanga, Ghana \\ ${ }^{4}$ Environmental and Natural Resources Management, Presbyterian University College, Ghana \\ Corresponding author: \\ A. Sadick, Soil Chemistry and Mineralogy Division, Council for Scientific and Industrial Research, Soil \\ Research Institute, PMB, Kumasi, Ghana \\ E-mail: sadick26589@itc.nl
}

\begin{abstract}
Climatic parameters such as temperature, rainfall, wind speed, relative humidity and sunshine hours were used to assess reference evapotranspiration and potential crop evapotranspiration of selected crops. The Penmann Monteith method for calculation of Reference Evapotranspiration, which has been incorporated in CROPWAT software, was used. Test crops included rice, tomato and pepper, which were part of the major crops cultivated in the Botanga irrigation scheme. Research findings indicated that temperature $(r=0.653)$ played a crucial role in assessing reference evapotranspiration and potential evapotranspiration. Temperature was lowest during the months from July to September due to lower solar radiation and higher rainfall. The potential crop evapotranspiration of rice, tomato and pepper were 697, 533 and $427 \mathrm{~mm} /$ season respectively. Rice growers will require more water for irrigation to ensure higher production due to its high evapotranspiration rate.
\end{abstract}

Key words: reference evapotranspiration, potential evapotranspiration, hydrological balance and climate, crop water requirement.

\section{Introduction}

Evapotranspiration (ET) can be described as the sum of soil evapotranspiration and plant transpiration from the earth's land surface to atmosphere. It is one of the crucial variables in the hydrological cycle which controls runoff volume or river discharge, irrigation water requirement and soil moisture contents (Mohan \& Arumugam, 1996).

Estimation of evapotranspiration is essential to irrigation managers in policy making, budgeting and planning. It is evident that direct impact of climate variability on water resources will be mainly through evapotranspiration. Hydrological changes constitute one of the most significant potential impacts on global climate change in the tropical regions (IPCC, 2007). It is now clear that climate variability will cause a steady rise in temperature and changes in rainfall pattern. Higher temperature will induce higher evapotranspiration, which, in turn, will affect the hydrological system and water resources (Shahid, 2011). Thus assessing the changes in ET due to climate variability is very important for water resources management in the long-term period. In the crop lands it is important to measure the possible changes in ET and probability of water losses due to climate variability.

Radiation, temperature, precipitation, relative humidity and wind speed are the major agro-climate factors responsible for evaporation from free water 
surface. Evaporation from a cropped soil is not only dependent on the meteorological factor but also on factors related to crop and to the available amount of soil moisture in the soil. Therefore, interest in obtaining evapotranspiration estimates and actual water use by different crops is increasing, which would make irrigation scheduling and water budget analysis more meaningful (Shirazi et al., 2011). Potential evapotranspiration (ETc) is the amount of water that is lost through the evaporation process from disease-free and well-fertilized crop field (FAO, 2005). The values of ETc from different crops differ as the ground cover, canopy properties and aerodynamic resistance of crops are different from one another. The reference evapotranspiration (ETo) also represents potential evapotranspiration of a wellwatered grass crop with an assumed height of $0.12 \mathrm{~m}$, a fixed surface resistance of $70 \mathrm{~s} / \mathrm{m}$ and albedo of 0.23 (Allen et al., 1998)

In Ghana, however, there is a lack of studies on evapotranspiration especially in the northern region where the temperature is high and rainfall is insufficient. Asare et al. (2011) estimated the potential evapotranspiration for a coastal savannah environment using six different methods. The study concluded that for coastal savannah environment of Ghana the Priestley-Taylor and Hargreaves-Samani models could be used in estimating the potential evapotranspiration in place of the Penman-Monteith Model. The result of a study by Abdul-Ganiyu,
Amaanatu and Korese (2012) on water use efficiency and productivity for rice (oryza sativa) in the Bontanga irrigation scheme of the northern region of Ghana indicated variations in water use efficiency and productivity. The variability was attributed to the irrigation practices, climatic conditions, late planting, overused seeds, pest pressure, weeds and the inherent characteristics of the soil among others. These studies did not consider the link between the potential evapotranspiration and irrigation water requirement for various crops. There is no doubt that climatic conditions play a significant role in crop productivity, especially those that are related to evapotranspiration. Therefore, the main objective of the study was to estimate and analyse potential evapotranspiration at Botanga irrigation scheme. The study also examined the influence of potential evapotranspiration on crop water requirement from irrigation for rice, tomato and pepper.

\section{$2 \quad$ Materials and methods}

\section{$2.1 \quad$ Location and climate}

Botanga irrigation scheme is located in the northern region of Ghana, in the Tolon Kumbungu district; it lies between latitude $9^{\circ} 30^{\prime \prime}$ and $9^{\circ} 35^{\prime \prime} \mathrm{N}$ and longitude $1^{\circ} 20^{\prime}$ and $1^{\circ} 04^{\prime}$ W. Figure 1 shows the study area.

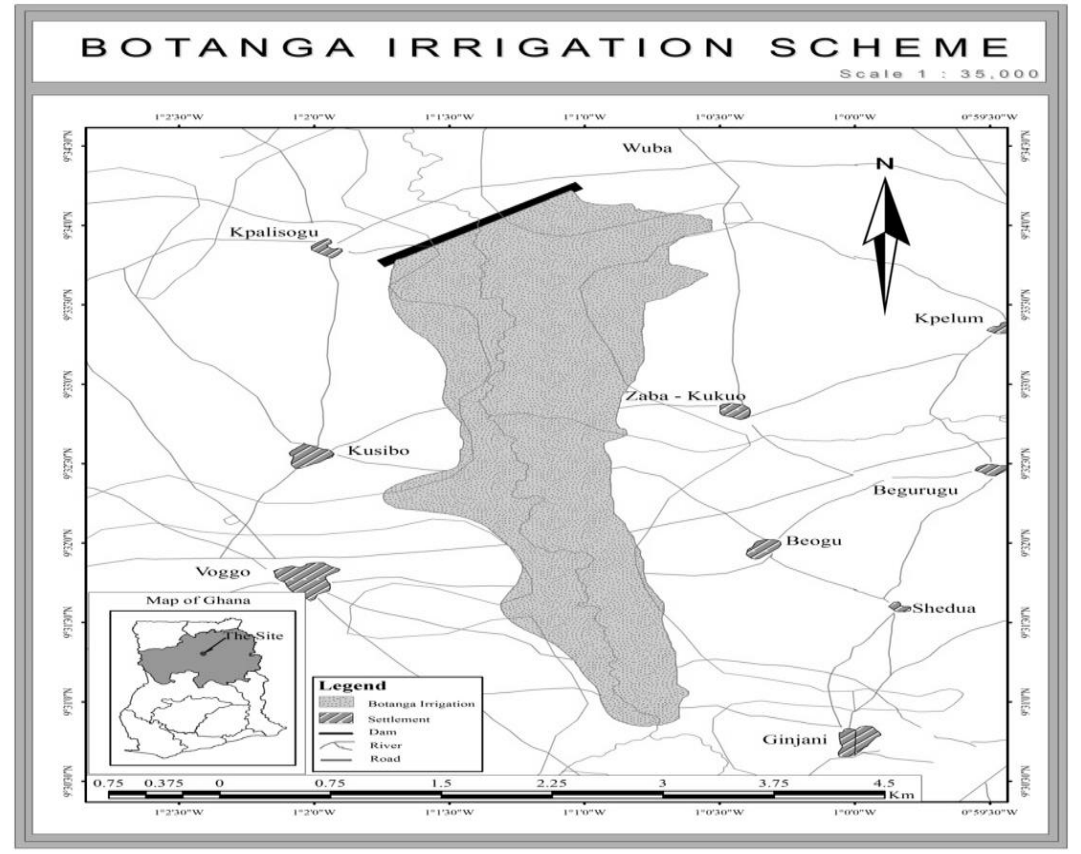

Figure 1. Map of Botanga irrigation scheme.

The cropping area is divided into two, upland and lowland, the upland is free draining soil and plots are designed for furrow irrigation. The upland area is for vegetables production and the lowland for rice production because of the nature of the soil that is heavily textured and irrigated by flooding (AbdulGaniyu et al., 2012).

The irrigation system is an earth fill dam of $12 \mathrm{~m}$ in height with a crest level of $5.00 \mathrm{~m}$. The spillway level is at an elevation of $5.8 \mathrm{~m}$ and the surface area at the spillway elevation is $770 \mathrm{~m}^{2}$. The reservoir capacity is 25 million $\mathrm{m}^{3}$. The dead storage elevation is about $1.52 \mathrm{~m}$ and the dead storage capacity is 5 million $\mathrm{m}^{3}$. The spillway type is drop inlet with a length of $83.7 \mathrm{~m}$ and a design discharge of $85 \mathrm{~m}^{3} / \mathrm{sec}$. An emergency spillway is also provided. The irrigation system has potential area of 570 ha and all 
the areas have been developed (Abdul-Ganiyu et al., 2012).

The system works under gravity from the dam through the canals, laterals to various farms. The maximum, minimum and dead storages of the reservoir are 25 million $\mathrm{m}^{3}, 20$ million $\mathrm{m}^{3}$ and 5 million $\mathrm{m}^{3}$ respectively, two (2) canals and twenty eight (28) laterals aid in the distribution of water to the farms. Thirteen (13) villages benefit from the dam, which includes Tibung, Kumbungu, Kpasogu,
Dalun, Wuba, Kukuo, Kpong, Saakuba, Yiplegu, Voggu, Kushibo, Zangbalwe and Bagli (AbdulGaniyu et al., 2012).

The total annual rainfall in the area is around 1,300 mm, which normally begins in March, reach a peak in September and then drop sharply in November (Fig. 2). Thereafter, there is a long dry period from December to the end of February, during which only negligible amounts of rain are received.

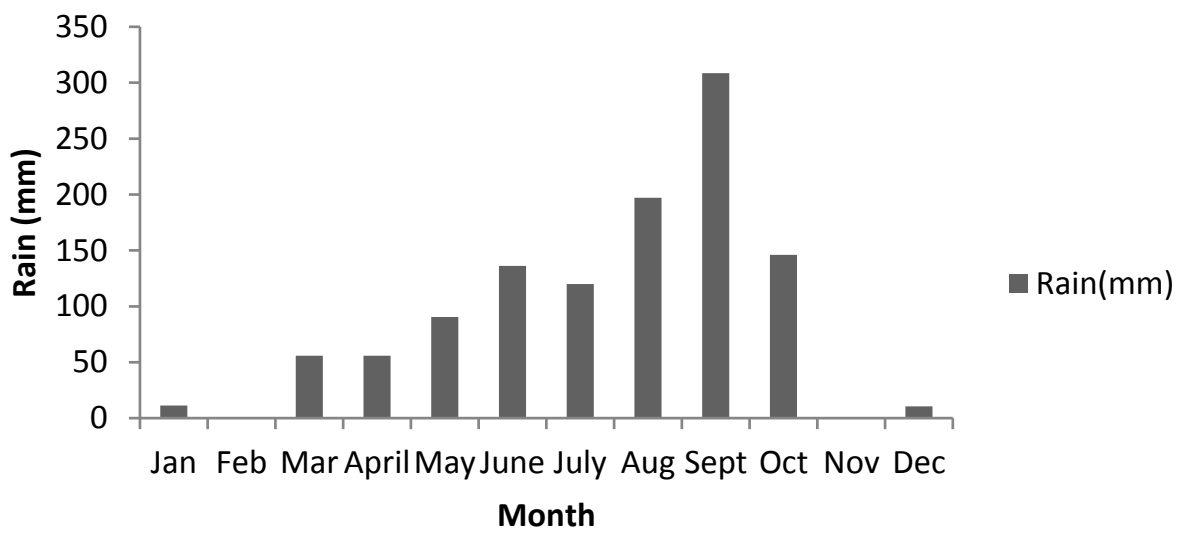

Figure 2. Average annual rainfall distribution in the northern region (1983-2002).

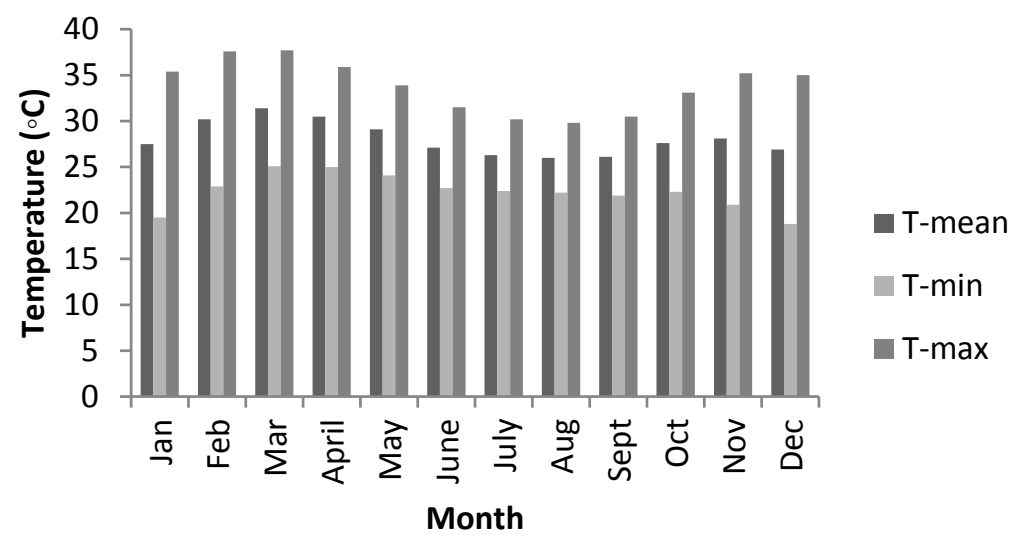

Figure 3. Mean monthly temperature in the northern region (1983-2002).

Mean monthly temperatures remain high throughout the year only falling around $26^{\circ} \mathrm{C}$ in August in Botanga. March and April are the hottest months recording nearly $30^{\circ} \mathrm{C}$ (Fig. 3).

\subsection{Estimation of reference and potential evapotranspiration}

In this study, meteorological data of twenty years of the northern region were collected from the Ghana Meteorological Agency (GMet) for the calculation of reference and potential evapotranspiration of rice, tomato and pepper, which are the major crops cultivated in the study area. This information will provide a good ground for planning and implementation of small and large scale irrigation projects and various possibilities of utilising excess rainwater (Shirazi et al., 2011). Solar radiation provides energy for evapotranspiration. Net radiation usually provides the upper limit for evapotranspiration especially in humid region. In the drier regions, evapotranspiration may exceed net radiation (Shirazi et al., 2011). Talukder (1988) reported that about $75-80 \%$ of the net radiation received at the surface is used for latent heat of evapotranspiration, and the rest is used for soil heat flux and sensible heat flux.

Allen et al. (1994) gave the methodology used for the calculations of crop evapotranspiration and developed it in the FAO Bulletin 56, 2002. The mentioned methodology begins with the calculation of Reference Evapotranspiration with the equation of Penmann Monteith, which is incorporated in CROPWAT software. Smith et al. (1991) and Smith (1992) reported that CROPWAT is a practical tool to help agro-meteorologists, agronomist and irrigation engineers to carry out standard calculations for evapotranspiration and crop water use studies, and 
more specifically the design and management of irrigation schemes.

Penman-Monteith equation developed in FAO bulletin by Allen et al. (1994) is as follows:

$$
\begin{aligned}
& E T_{o}= \\
& \quad \frac{0.408 \Delta\left(R_{n}-G\right)+\gamma\left(\frac{900}{T}+273\right) u_{2}\left(e_{s}-e_{a}\right)}{\Delta+\gamma\left(1+0.3 u_{2}\right)}
\end{aligned}
$$

where $E T_{o}$ is reference crop evaporation ( $\mathrm{mm} /$ day), $R_{n}$ is net radiation at the crop surface $\left(\mathrm{MJm}^{-2} \mathrm{day}^{-1}\right), G$ is soil heat flux density $\left(\mathrm{MJm}^{-2} \mathrm{day}^{-1}\right)$, $\mathrm{T}$ is mean daily air temperature at $2 \mathrm{~m}$ height $\left({ }^{\circ} \mathrm{C}\right), u_{2}$ is wind speed at $2 \mathrm{~m}$ height $\left(\mathrm{ms}^{-1}\right), e_{s}$ is saturated vapour pressure $(\mathrm{kPa}), e_{a}$ is actual vapour pressure $(\mathrm{kPa}), \Delta$ is slope vapour pressure curve $\left(\mathrm{kPa}^{\circ} \mathrm{C}^{-1}\right), \mathrm{e}_{\mathrm{s}}-\mathrm{e}_{\mathrm{a}}$ is saturated vapour pressure deficit $(\mathrm{kPa})$.

$$
\gamma=\frac{C_{p} P}{\varepsilon \lambda}=0.655 \times 10^{-3} P
$$

where $\gamma$ is psychometric constant $\left(\mathrm{kPa}^{\circ} \mathrm{C}^{-1}\right), P$ is atmospheric pressure $(\mathrm{kPa}), \Lambda$ is latent heat of vaporization, $2.45\left(\mathrm{MJkg}^{-1}\right), C_{p}$ is specific heat at constant pressure, $1.013 \times 10^{-3}\left(\mathrm{MJkg}^{-1 \circ} \mathrm{C}^{-1}\right), E$ is ratio molecular weight of water vapour/dry air, 0.622 .

$$
P=101.3\left(\frac{293-0.0065 Z}{293}\right)^{5.26}
$$

where $Z$ is elevation above sea level (m).

As saturated vapour pressure is related to air temperature, it is calculated from air temperature. The relationship is given by:

$$
e^{0}(T)=0.6108 \exp \left(\frac{17.27 T}{T+237.3}\right)
$$

where $e^{\circ}$ is saturated vapour pressure at the air temperature $\mathrm{T}(\mathrm{kPa}), T$ is air temperature.

Due to the non-linearity of the above equation, the mean saturated vapour pressure for a day, week, decade or month should be computed as the mean between the saturated vapour pressure at the mean daily maximum and minimum air temperature for that period:

$$
e_{s}=\frac{e^{0}\left(T_{\max }\right)+e^{0}\left(T_{\min }\right)}{2}
$$

For the calculation of evapotranspiration, the slope of the relationship between saturated vapour pressure and temperature is required. The slope of the curve at a given temperature is given by:

$$
\Delta=\frac{4098\left[0.6108 \exp \left(\frac{17.27 T}{T+237.3}\right)\right]}{(T+237.3)^{2}}
$$

The actual vapour pressure can be calculated from the relative humidity. Depending on the availability of the humidity data, different equations should be used:

$$
e_{a}=\frac{\frac{e^{0}\left(T_{\min }\right) R H_{\max }}{100}+\frac{e^{0}\left(T_{\max }\right) R H_{\min }}{100}}{2}
$$

where $e_{a}$ is actual vapour pressure $(\mathrm{kPa}), e^{\circ}\left(T_{\min }\right)$ is saturated vapour pressure at daily minimum temperature, $e^{\circ}\left(T_{\max }\right)$ is saturated vapour pressure at daily maximum temperature, $R H_{\min }$ is minimum relative humidity $(\%) ; R H_{\max }$ is maximum relative humidity (\%).

In this study, Botanga meteorological station was selected for this purpose because it is situated in the irrigation area. Once the $E T_{o}$ value is calculated, the potential crop evapotranspiration is calculated by the product of $E T_{o}$ and crop coefficient $\left(\mathrm{K}_{\mathrm{c}}\right)$ :

$$
E T_{c}=E T_{0} \times K_{c}
$$

The weather measurements were taken at $2 \mathrm{~m}$ above the surface of the green grass and the average climatic data were taken from 1983 to 2002. The major crops which were cultivated in Botanga irrigation area were tomato and pepper. These crops are mostly cultivated on the upland soils, and rice is predominantly grown on the valley bottom soils (lowland), which is heavily textured and cultivated by flooding. Adams et al. (2014) reported that laboratory analysis of the soil in the irrigation area revealed that upland soils where vegetables are cultivated are sandy loam and the lowland soils where rice is cultivated are clayed soils. FAO (1985) reported that rice grows well in clayed soil but can be cultivated in sandy loam with high water table.

\subsection{Statistical analysis}

One-way analysis of variance (ANOVA) was used to test variations of various climatic parameters. Pearson correlation coefficient was calculated to test the degree of relationship between the climatic parameters and evapotranspiration. The statistical analysis was carried out using software packages SPSS 20 .

\section{Results and discussion}

The results obtained when a 20 -year period was used with the FAO-Penman Monteith method to estimate the reference crop evapotranspiration $\left(\mathrm{ET}_{\mathrm{o}}\right)$ for the study area were shown in Table 1 below. This showed that $\mathrm{ET}_{\mathrm{o}}$ varied from a minimum value of $4.49 \mathrm{~mm} /$ day in September to the highest value of $4.94 \mathrm{~mm} /$ day in April. Adams et al. (2014) reported that $\mathrm{ET}_{\mathrm{o}}$ values in the upper east region of Ghana are generally higher than those in the northern region. 


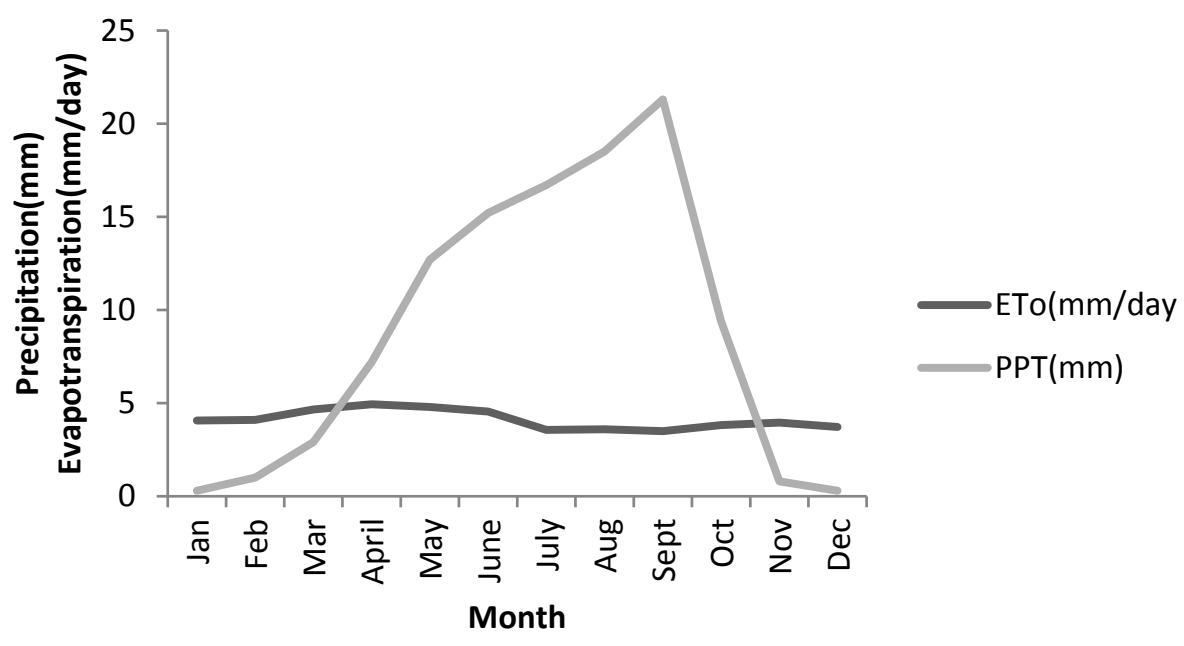

Figure 4. Variation of $E T_{o}$ and precipitation at Botanga.

The elements of water balance analysis for Botanga irrigation scheme is presented in figure 4 . The results showed that from January to March and November to December $\mathrm{ET}_{\mathrm{o}}$ were higher than precipitation. This implies that irrigation was necessary to grow crops during these periods of nonavailability of sufficient amount of precipitation and high atmospheric evaporative demand by crops (Shirazi et al., 2011). Moreover, from April to October, precipitation was much higher than $\mathrm{ET}_{0}$. There was abundant supply of precipitation during these periods, and it might cause sudden flood which, in turn, destroy the root zone of crops.

There was significant difference $(\mathrm{P}<0.05)$ in maximum temperature and solar radiation. Temperature values were maximum during the Harmattan season. Low temperatures recorded between the months of June and September were due to lesser solar radiation and low atmospheric temperature. In Ghana, higher temperatures are recorded in upper east and upper west regions and evapotranspiration is expected to be high in those regions (Table 2). The results also show that the temperature plays a significant role in assessing reference evapotranspiration $\left(\mathrm{ET}_{\mathrm{o}}\right)$ compared with other climatic parameters which have insignificant correlation with reference evapotranspiration.

Potential crop evapotranspiration of rice, tomato and pepper were found to be 697, 533 and $427 \mathrm{~mm} /$ season. A study at Tono irrigation scheme in the upper east region of Ghana showed that potential crop evapotranspiration of rice is higher than that in Botanga irrigation scheme. This is as a result of higher temperature recorded at Tono irrigation scheme during that period (Adams et al., 2014).

Table 1. Analysis of climate parameters and reference crop evapotranspiration.

\begin{tabular}{|c|c|c|c|c|c|c|c||}
\hline Month & $\begin{array}{c}\text { Min. Temp., } \\
{ }^{\circ} \mathbf{C}\end{array}$ & $\begin{array}{c}\text { Max. Temp., } \\
{ }^{\circ} \mathbf{C}\end{array}$ & $\begin{array}{c}\text { Humidity, } \\
\mathbf{\%}\end{array}$ & $\begin{array}{c}\text { Wind, } \\
\text { km/day }\end{array}$ & $\begin{array}{c}\text { Sun } \\
\text { hours }\end{array}$ & $\begin{array}{c}\text { Rad, } \\
\mathbf{M J} / \mathbf{m}^{2} / \mathbf{d a y}\end{array}$ & $\begin{array}{c}\text { ETo } \\
\text { mm/day }\end{array}$ \\
\hline January & 19.5 & 35.4 & 26 & 12 & 15.5 & 29.8 & 4.07 \\
\hline February & 22.9 & 37.6 & 28 & 13 & 11.2 & 25.3 & 4.1 \\
\hline March & 25.1 & 37.7 & 39 & 13 & 10 & 24.7 & 4.66 \\
\hline April & 25 & 35.9 & 56 & 14 & 9.5 & 24.2 & 4.94 \\
\hline May & 24 & 33.9 & 66 & 13 & 9.4 & 23.5 & 4.79 \\
\hline June & 22.7 & 31.5 & 76 & 12 & 9.3 & 22.8 & 4.55 \\
\hline July & 22.4 & 30.2 & 79 & 13 & 5.6 & 17.5 & 3.56 \\
\hline August & 22.2 & 29.8 & 81 & 12 & 5.6 & 17.9 & 3.6 \\
\hline September & 21.9 & 30.5 & 82 & 9 & 5.3 & 17.4 & 3.49 \\
\hline October & 22.3 & 33.1 & 73 & 8 & 7.1 & 19.4 & 3.82 \\
\hline November & 20.9 & 35.2 & 51 & 8 & 10 & 22.3 & 3.95 \\
\hline December & 18.8 & 35 & 35 & 10 & 12.2 & 24.6 & 3.72 \\
\hline Mean & $\mathbf{2 2 . 3 1}$ & $\mathbf{3 3 . 8 2}$ & $\mathbf{5 7 . 6 1}$ & $\mathbf{1 1 . 4 2}$ & $\mathbf{9 . 2 3}$ & $\mathbf{2 2 . 4 5}$ & $\mathbf{4 . 1 0}$ \\
\hline STD & $\mathbf{1 . 9 3}$ & $\mathbf{2 . 7 8}$ & $\mathbf{2 1 . 3 7}$ & $\mathbf{2 . 1 1}$ & $\mathbf{3 . 0 1}$ & $\mathbf{3 . 7 7}$ & $\mathbf{0 . 5 1}$ \\
\hline Variance & $\mathbf{3 . 7 1}$ & $\mathbf{7 . 7 9}$ & $\mathbf{4 5 6 . 7 8}$ & $\mathbf{4 . 4 5}$ & $\mathbf{9 . 1 0}$ & $\mathbf{1 4 . 2 0}$ & $\mathbf{0 . 2 6}$ \\
\hline
\end{tabular}

From the results of the estimation, it was revealed that the highest reference evapotranspiration $\left(\mathrm{ET}_{\mathrm{o}}\right)$ occurred between February and May. This implies that the higher the air temperature is recorded, the higher the $\mathrm{ET}_{\mathrm{o}}$ is. This may be attributed to the fact that most work of the planting season is done within this time frame of the year, the amount of available water in the soil might have increased due to some recorded rainfall in April and May as shown in Table 5. The lowest $\mathrm{ET}_{\mathrm{o}}$ values were recorded between July and September, which also corresponded with the lowest maximum temperatures 
for the same months. Also, the humidity within these three months was the highest for the period. This implies that when the temperature is low, the humidity will be high and evapotranspiration will be low. It has been said that evapotranspiration is influenced by the meteorological factors, and the findings of the studies have confirmed this assertion or findings. Within these months under discussions, it was observed that the peak of the raining season was reached within July and September. It could be inferred that the amount of moisture in the soil will be high, hence available water in the soil would also be high, making more water available to plants for evapotranspiration to occur, but it is regulated by the amount of moisture already in the atmosphere (humidity) and the temperature. The least $\mathrm{ET}_{\mathrm{o}}$ value was recorded in July when the lowest sunshine and solar radiations were recorded with the lowest of the highest humidity. This also implies a number of these meteorological factors come together to influence the reference evapotranspiration.

Table 2. Correlation matrix of climatic parameters and $E T_{o}$ in Botanga irrigation scheme.

\begin{tabular}{|c|c|c|c|c|c|c|c|c||}
\hline \multirow{2}{*}{ Min Temp. } & Min. Temp. & Max. Temp. & Humidity & Wind & $\begin{array}{c}\text { Sun } \\
\text { hours }\end{array}$ & Rad & ET \\
\hline & Pearson Correlation & 1 & & & & & & \\
\hline & Sig. (2-tailed) & & & & & & & \\
\hline \multirow{2}{*}{ Max Temp. } & Pearson Correlation & 0.150 & 1 & & & & & \\
\hline & Sig. (2-tailed) & 0.643 & & & & & & \\
\hline \multirow{2}{*}{ Humidity } & Pearson Correlation & 0.253 & $-0.882^{* *}$ & 1 & & & & \\
\cline { 2 - 10 } & Sig. (2-tailed) & 0.428 & 0.000 & & & & & \\
\hline \multirow{2}{*}{ Wind speed } & Pearson Correlation & 0.548 & 0.204 & -0.170 & 1 & & & \\
\hline & Sig. (2-tailed) & 0.065 & 0.524 & 0.597 & & & & \\
\hline \multirow{2}{*}{ Sun hours } & Pearson Correlation & -0.362 & $0.732^{* *}$ & $-0.893^{* *}$ & 0.159 & 1 & & \\
\hline & Sig. (2-tailed) & 0.248 & 0.007 & 0.000 & 0.622 & & & \\
\hline \multirow{2}{*}{ Radiation } & Pearson Correlation & -0.141 & $0.791^{* *}$ & $-0.876^{* *}$ & 0.324 & $0.972^{* *}$ & 1 & \\
\hline & Sig. (2-tailed) & 0.662 & 0.002 & 0.000 & 0.304 & 0.000 & & \\
\hline \multirow{2}{*}{ ET } & Pearson Correlation & $0.653^{*}$ & 0.538 & -0.247 & 0.569 & 0.364 & 0.543 & 1 \\
\hline & Sig. (2-tailed) & 0.021 & 0.071 & 0.439 & 0.053 & 0.245 & 0.068 & \\
\hline
\end{tabular}

* Correlation is significant at the 0.05 level (2-tailed)

** Correlation is significant at the 0.01 level (2-tailed)

The results of the correlation analysis as in Table 2 indicate that the minimum temperature $(\mathrm{r}=0.653)$ favoured higher evapotranspiration and was significant $(\mathrm{p}<0.021)$. Even though the correlation result for humidity was low, it was negatively correlated $(\mathrm{r}=-0.247)$. This implies that the increase in humidity related to decrease in evapotranspiration.
Crop Water Requirement. Irrigation water requirements differed from the crops studied. The daily crop evapotranspiration increased from $0.46 \mathrm{~mm} /$ day in January to $5.23 \mathrm{~mm}$ /day in early May, with the highest being in April $(5.56 \mathrm{~mm} /$ day $)$ as in Table 3 for rice.

Table 3. Evapotranspiration and irrigation requirement for rice.

\begin{tabular}{|c|c|c|c|c|c|c|c|}
\hline \multicolumn{8}{|c|}{ Station: Botanga Date of Transplant: 28-January } \\
\hline Month & Decade & Stage & $\begin{array}{c}K_{c}, \\
\text { coeff }\end{array}$ & $\begin{array}{c}\mathbf{E T}, \\
\mathbf{m m} / \mathbf{d a y}\end{array}$ & $\begin{array}{c}\text { ETc, } \\
\text { mm/decade }\end{array}$ & $\begin{array}{l}\text { Eff. rain, } \\
\text { mm/decade }\end{array}$ & $\begin{array}{l}\text { Irr. req., } \\
\text { mm/decade }\end{array}$ \\
\hline Dec & 3 & Nurs & 1.2 & 0.46 & 1.4 & 0.2 & 1.4 \\
\hline \multirow[t]{3}{*}{ Jan } & 1 & Nurs/LPr & 1.16 & 1.59 & 15.9 & 0.8 & 63.9 \\
\hline & 2 & Nurs/LPr & 1.06 & 4.33 & 43.3 & 0.7 & 42.6 \\
\hline & 3 & Init & 1.08 & 4.39 & 48.3 & 1.6 & 396.5 \\
\hline \multirow[t]{3}{*}{ Feb } & 1 & Init & 1.1 & 4.5 & 45 & 2.2 & 42.8 \\
\hline & 2 & Deve & 1.1 & 4.51 & 45.1 & 2.8 & 42.3 \\
\hline & 3 & Deve & 1.11 & 4.75 & 38 & 4.9 & 33 \\
\hline \multirow[t]{3}{*}{ Mar } & 1 & Deve & 1.12 & 4.99 & 49.9 & 6.7 & 43.2 \\
\hline & 2 & Mid & 1.12 & 5.24 & 52.4 & 8.4 & 44 \\
\hline & 3 & Mid & 1.13 & 5.36 & 58.9 & 12.7 & 46.3 \\
\hline \multirow[t]{3}{*}{ Apr } & 1 & Mid & 1.13 & 5.46 & 54.6 & 17.2 & 37.4 \\
\hline & 2 & Mid & 1.13 & 5.56 & 55.6 & 21.2 & 34.5 \\
\hline & 3 & Late & 1.12 & 5.49 & 54.9 & 25.4 & 29.6 \\
\hline \multirow[t]{3}{*}{ May } & 1 & Late & 1.08 & 5.23 & 52.3 & 30.3 & 22 \\
\hline & 2 & Late & 1.03 & 4.92 & 49.2 & 34.8 & 14.4 \\
\hline & 3 & Late & 0.98 & 4.62 & 32.4 & 22.9 & 0 \\
\hline Total & - & - & - & - & 697.2 & 192.7 & 893.8 \\
\hline
\end{tabular}

Nurs = Nursery, $\mathrm{LPr}=$ Land preparation, Init = Initial stage, Deve = Development stage, Mid = Mid-Season stage, Late $=$ Late season stage, $K_{c}=$ Crop Coefficient, $E T_{c}=$ Crop Evapotranspiration $(\mathrm{mm} /$ day $), E T_{c}=$ Crop Evapotranspiration $(\mathrm{mm} /$ decade $)$, Eff. rain $=$ Effective rain $(\mathrm{mm} /$ decade $)$, Irr. Req. $=$ Irrigation Requirement $(\mathrm{mm} /$ decade $)$. 
This generally indicates that during the dry season a lot of water was lost by crops from evapotranspiration processes. This also corresponds to the month that recorded the highest reference crop evapotranspiration $(4.94 \mathrm{~mm} /$ day $)$ as in Table 1 . The highest irrigation water requirement was in late March $46.3 \mathrm{~mm} /$ decade for the rice. This observation occurred when the crop was at the middle of its development stages where more water will be required for photosynthesis and fruiting. Tomato also exhibited similar variation where the daily crop evapotranspiration increased from November $(0.46 \mathrm{~mm} /$ day $)$ to late February $(4.67 \mathrm{~mm} /$ day $)$ and started dropping in early March ( $3.67 \mathrm{~mm} /$ day $)$ as in Table 4.

Table 4. Evapotranspiration and irrigation requirement for tomato.

\begin{tabular}{|c|c|c|c|c|c|c|c||}
\hline Month & Decade & Stage & $\begin{array}{c}\mathbf{K}_{\mathbf{c}}, \\
\text { Coeff }\end{array}$ & $\begin{array}{c}\mathbf{E T}_{\mathbf{c}}, \\
\mathbf{m m} / \mathbf{d a y}\end{array}$ & $\begin{array}{c}\mathbf{E T}_{\mathbf{c}}, \\
\mathbf{m m} / \mathbf{d e c a d e}\end{array}$ & $\begin{array}{c}\text { Eff rain, } \\
\mathbf{m m} / \mathbf{d e c a d e}\end{array}$ & $\begin{array}{c}\text { Irr. req., } \\
\mathbf{m m} / \mathbf{d e c a d e}\end{array}$ \\
\hline \multirow{3}{*}{ Nov } & 1 & Init & 0.6 & 2.34 & 23.4 & 7.7 & 15.8 \\
\cline { 2 - 8 } & 2 & Init & 0.6 & 2.37 & 23.7 & 0 & 23.7 \\
\cline { 2 - 8 } & 3 & Init & 0.6 & 2.32 & 23.2 & 0.3 & 22.9 \\
\hline \multirow{3}{*}{ Dec } & 1 & Deve & 0.67 & 2.54 & 25.4 & 1.4 & 24 \\
\cline { 2 - 8 } & 2 & Deve & 0.8 & 2.97 & 29.7 & 0.8 & 28.9 \\
\cline { 2 - 8 } & 3 & Deve & 0.93 & 3.58 & 39.4 & 0.9 & 38.5 \\
\hline \multirow{3}{*}{ Jan } & 1 & Mid & 1.07 & 4.21 & 42.1 & 0.8 & 41.3 \\
\cline { 2 - 8 } & 2 & Mid & 1.11 & 4.53 & 45.3 & 0.7 & 44.6 \\
\cline { 2 - 8 } & 3 & Mid & 1.11 & 4.54 & 49.9 & 1.6 & 48.4 \\
\hline \multirow{3}{*}{ Meb } & 1 & Mid & 1.11 & 4.55 & 45.5 & 2.2 & 43.3 \\
\cline { 2 - 8 } & 2 & Mid & 1.11 & 4.56 & 45.6 & 2.8 & 42.8 \\
\cline { 2 - 8 } & 3 & Late & 1.09 & 4.67 & 37.4 & 4.9 & 32.5 \\
\cline { 2 - 8 } & 2 & Late & 0.99 & 4.41 & 44.1 & 6.7 & 37.4 \\
\cline { 2 - 8 } & 3 & Late & 0.86 & 4.02 & 40.2 & 8.4 & 31.9 \\
\hline Total & - & - & - & - & $\mathbf{5 3 3 . 3}$ & $\mathbf{4 4 . 8}$ & $\mathbf{4 8 8}$ \\
\hline \hline
\end{tabular}

The highest irrigation water requirement was in late January ( $48.4 \mathrm{~mm} / \mathrm{decade})$ for the tomatoes. This observation occurred when the crop was in the middle of its development. Similar trend was observed for pepper. The highest daily crop evapotranspiration increased from November $(2.34 \mathrm{~mm} /$ day $)$ to late February (4.21 mm/day) and started dropping in March (3.99 mm/day) as in Table 5. Also, the highest irrigation water requirement for pepper was in late January (43.8 mm/decade). The total crop evapotranspiration was high for rice (697.2 $\mathrm{mm} /$ decade) than tomatoes $(533.3 \mathrm{~mm} /$ decade $)$ and pepper $(426.8 \mathrm{~mm} /$ decade). These differences may be due to many factors such as soil type, plant physiology, farming method and irrigation method used. In total, the irrigation water requirement for rice ( $893.8 \mathrm{~mm} /$ decade) was higher than the tomatoes (488.0 $\mathrm{mm} /$ decade) and paper (399.6 mm/decade). This implies that if irrigation is not done to make-up the plant water requirement, the crops may reach their wilting point and die. This will ultimately affect the yields of the crops, affects farmers' income and contribute to aggravate poverty in the region. Higher irrigation water requirements of 962 and $1,114 \mathrm{~mm}$ were recorded for rice in Taiwan (Kuo et al., 2006).

Table 5. Evapotranspiration and irrigation requirement for pepper.

\begin{tabular}{|c|c|c|c|c|c|c|c|}
\hline Month & Decade & Stage & $\begin{array}{c}\mathbf{K}_{\mathrm{c}}, \\
\text { Coeff }\end{array}$ & $\begin{array}{c}\mathbf{E T}_{\mathrm{c}}, \\
\mathbf{m m} / \mathbf{d a y}\end{array}$ & $\begin{array}{c}\text { ET } \\
\text { mm/decade }\end{array}$ & $\begin{array}{c}\text { Eff rain, } \\
\mathrm{mm} / \text { decade }\end{array}$ & $\begin{array}{l}\text { Irr. req., } \\
\text { mm/decade }\end{array}$ \\
\hline \multirow[t]{3}{*}{ Nov } & 1 & Init & 0.6 & 2.34 & 4.7 & 1.5 & 4.7 \\
\hline & 2 & Init & 0.6 & 2.37 & 23.7 & 0 & 23.7 \\
\hline & 3 & Init & 0.6 & 2.32 & 23.2 & 0.3 & 22.9 \\
\hline \multirow[t]{3}{*}{ Dec } & 1 & Deve & 0.6 & 2.29 & 22.9 & 1.4 & 21.5 \\
\hline & 2 & Deve & 0.69 & 2.56 & 25.6 & 0.8 & 24.8 \\
\hline & 3 & Deve & 0.81 & 3.11 & 34.2 & 0.9 & 33.4 \\
\hline \multirow[t]{3}{*}{ Jan } & 1 & Deve & 0.94 & 3.69 & 36.9 & 0.8 & 36.1 \\
\hline & 2 & Mid & 1.01 & 4.11 & 41.1 & 0.7 & 40.4 \\
\hline & 3 & Mid & 1.01 & 4.12 & 45.3 & 1.6 & 43.8 \\
\hline \multirow[t]{3}{*}{ Feb } & 1 & Mid & 1.01 & 4.13 & 41.3 & 2.2 & 39.1 \\
\hline & 2 & Mid & 1.01 & 4.14 & 41.4 & 2.8 & 38.7 \\
\hline & 3 & Late & 0.98 & 4.21 & 33.7 & 4.9 & 28.8 \\
\hline \multirow[t]{2}{*}{ Mar } & 1 & Late & 0.91 & 4.07 & 40.7 & 6.7 & 34 \\
\hline & 2 & Late & 0.86 & 3.99 & 12 & 2.5 & 7.8 \\
\hline Total & - & - & - & - & 426.8 & 27 & 399.6 \\
\hline
\end{tabular}




\section{Conclusions}

The study was done at Botanga irrigation scheme to assess the evapotranspiration levels of some major crop using FAO Penman-Monteith method. The results showed that temperature played a significant role in assessing reference evapotranspiration compared to other climatic parameters. The temperature was lowest during the months from July to September due to lower solar radiation and higher rainfall. Potential crop evapotranspiration was higher in rice than tomato and pepper which has the lowest potential crop evapotranspiration. The implication of the study for farmers is that if water availability is a limiting factor for crop production, the planting of pepper becomes more favourable than tomatoes and rice since the irrigation water requirement is low. The major setback of the study is the inability to relate the irrigation water requirement with the physiology of the plant and the crop coefficient with the evapotranspiration rate of each crop studied. The used climatic data may not reflect the current trend of crop water requirement as they ranged from 1983 to 2002, and such climatic variations over the years may be another weakness. However, lack of these data did not adversely affect the results obtained from this study. Therefore, further study to examine the physiology of the crops and the irrigation water requirement, influence of crop coefficient on evapotranspiration are recommended.

\section{References}

Abdul-Ganiyu, S., Amaanatu M.K. and Korese, J.K. (2012) Water use efficiency and productivity for rice (Oryza Sativa) in the Botanga irrigation scheme of northern region of Ghana. Agricultural Science Research Journal 2(7): 362-368. Available at: http://resjournals.com/ ARJ/Pdf/2012/July/Abdul-Ganiyu\%20et\%20al.pdf.

Adams, S., Quansah, G.W., Issaka, R.N., Asamoah, E.A., Nketia, K.A., and Amfo-Otu, R. (2014) Water requirements of some selected crops in Tono irrigation area. Journal of Biodiversity and Environmental Sciences 4(3): 246-257. Available at: http://www.innspub.net/wp-content/uploads/2014/03/ JBES-Vol4No3-p246-257.

Allen, R. G., Pereira, L S., Raes, D., and Smith, M. (1998). Crop evapotranspiration - guidelines for computing crop water requirements. FAO Irrigation and Drainage paper 56 (p. 300). Rome, Italy: FAO. Available at: http://www.engr.scu.edu/ emaurer/classes/ceng140_wat res/handouts/FAO_56_Evapotranspiration.pdf.

FAO (1997). Irrigation potential in Africa: A basin approach. p. 54. Rome: Food and Agriculture Organization of the United Nations.

Asare, D. K. Banini, G. K., Ayeh E.O., and Amenorpe, G. (2011) Estimation of Potential evapotranspiration for coastal Savannah environment by comparision of different methods. International Journal of Sustainable Agriculture 3(2): 65-70. Available at: http://www.idosi.org/ijsa/3(2)11/6.pdf.

Food and Agriculture Organization (FAO). (1992). CROPWAT: A Computer Program for Irrigation
Planning and Management, by M. Smith. FAO Irrigation and Drainage Paper No. 46. Rome.

Ghana Meteorological Agency (2013). Available at: http://www.meteo.gov.gh (20/11/2013).

IPCC (2007). Summary for Policymakers. In: Parry, M.L., Canziani, O.F., Palutikof, J.P., Van der Linden, P.J., and Hanson, C.E. (Eds.), Climate Change 2007: Impacts, Adaptation and Vulnerability. Contribution of Working Group II to the Fourth Assessment Report of the Intergovernmental Panel on Climate Change. Cambridge University Press, Cambridge, UK. Available at: https://www.ipcc.ch/pdf/assessment-report/ar4/wg2/ ar4-wg2-spm.pdf (15/10/2013).

Kuo, S.F., Ho, S.S., and Liu, C.W. (2006) Estimation irrigation water requirements with derived crop coefficients for upland and paddy crops in ChiaNan Irrigation Association, Taiwan. Agricultural Water Management 82: 433-451. doi: http://dx.doi.org/ 10.1016/j.agwat.2005.08.002.

Mohan, S. and Arumugam, N. (1996) Relative importance of meteorological variables in evapotranspiration: Factor analysis approach. Water Resources Management 10(1): 1-20. doi: http://dx.doi.org/ 10.1007/BF00698808.

Shahid, S. (2011) Impacts of Climate Change on Irrigation Water Demand in Northwestern Bangladesh. Climatic Change 105(3-4): 433-453. doi: http://dx.doi.org/ 10.1007/s10584-010-9895-5.

Shirazi, S.M., Ismail, Z, Shatirah A, Sholichin, M. and Islam, M.A. (2011) Climatic parameters and net irrigation requirements of crops. International Journal of the Physical Sciences 6(1): 15-26

Smith, M.A. (1992). Senior Irrigation Management Officer Water Resources, Development and Management Service FAO, Rome, Italy.

Smith, M.A., Monteith, R., Pereira, J.L., Pereira, L.A., Perner, A., Segreen, A. (1991). Report on the Expert Consultants on Procedures for Revision of FAO Guidelines for Prediction of Crop Water Requirements. Rome, Italy: FAO.

Talukder, M.S.U. (1988) Radiation and energy balance from standard metrological observations in Bangladesh. Journal of the Institution of Engineers, Bangladesh 15(1): 17-22. 


\title{
Botangos drẻkinimo sistemos Šiaurès Ganos regione potencialaus suminio garavimo îvertinimas
}

\author{
Adams Sadick ${ }^{1}$, Isaac Owusu Ansah ${ }^{1}$, Aaron Owusu Badu' ${ }^{1}$, Kwabena \\ Abrefa Nketia ${ }^{2}$, Eric Asamoah ${ }^{2}$, Jerry Asaana ${ }^{3}$, Richard Amfo-Otu ${ }^{4}$
}

\author{
${ }^{1}$ Dirvožemio chemijos ir mineralogijos departamentas, Moksliniu ir pramoniniu tyrimu taryba, Dirvožemio \\ tyrimu institutas, Kumasi, Gana \\ ${ }^{2}$ Dirvožemio kilmès, tyrimo ir vertinimo departamentas, Mokslinių ir pramoniniu tyrimu taryba, Dirvožemio \\ tyrimu institutas, Kumasi, Gana \\ ${ }^{3}$ Bolgatangos politechnikos institutas, Bolgatanga, Gana \\ ${ }^{4}$ Aplinkosaugos ir gamtos išteklių valdymo departamentas, Presbiterionu universiteto koledžas, Gana
}

Sąlyginiam suminiam garavimui (evapotranspiracijai) ir potencialiam pasirinktų augalų suminiam garavimui įvertinti buvo naudojami tokie klimato parametrai, kaip temperatūra, kritulių kiekis, vèjo greitis, santykinis drègnis ir saulètos valandos. Šiame tyrime sąlyginis suminis garavimas buvo apskaičiuotas Penmann Monteith metodu naudojant CROPWAT programinę įrangą. Buvo tirti ryžiai, pomidorai ir pipirai, vieni iš pagrindinių augalų, sudarančių Botangos drèkinimo schemą. Tyrimo rezultatai parodè, kad temperatūra $(r=0.653)$ buvo pagrindinis veiksnys vertinant sąlyginị ir potencialų suminị garavimą. Dèl mažesnès saulès spinduliuotès ir padidejusio kritulių kiekio žemiausia temperatūra buvo liepos-rugsèjo mènesiais. Buvo nustatytos potencialios ryžių, pomidorų ir pipirų suminio garavimo reikšmès: atitinkamai 697, 533 ir 427 mm per sezoną. Dẻl didelès ryžių suminio garavimo reikšmès augintojams siekiant didesnio derliaus ryžiams drëkinti reikès naudoti daugiau vandens.

Raktiniai žodžiai: salyginis suminis garavimas, potencialus suminis garavimas, hidrologinis balansas ir klimatas, pasèlių vandens poreikis. 